\title{
Gain and loss of subcutaneous and abdominal adipose tissue depot mass of German Holstein dairy cows with different body conditions during the transition period
}

\author{
G. Szura, ${ }^{1}$ S. Schäfers, ${ }^{2 *}$ D. von Soosten, ${ }^{2}$ U. Meyer, ${ }^{2}$ J. Klüß, ${ }^{2}$ G. Breves,${ }^{3}$ S. Dänicke, ${ }^{2}$ J. Rehage,${ }^{1} \dagger$ \\ and L. Ruda ${ }^{1}$ \\ ${ }^{1}$ Clinic for Cattle, University of Veterinary Medicine Hannover, Foundation, 30173 Hannover, Germany \\ ${ }^{2}$ Institute of Animal Nutrition, Friedrich-Loeffler-Institute, Federal Research Institute for Animal Health, 38116 Braunschweig, Germany \\ ${ }^{3}$ Institute for Physiology and Cell Biology, University of Veterinary Medicine Hannover, Foundation, 30173 Hannover, Germany
}

\begin{abstract}
Subcutaneous adipose tissue (SCAT) and abdominal adipose tissue (AAT) depots are mobilized during the fresh cow period (FCP) and early lactation period (ELP) to counteract the negative energy balance (NEB). Earlier studies suggested that fat depots contribute differently to lipomobilization and may vary in functionality. Differences between the adipose depots might influence the development of metabolic disorders. Thus, the gain and loss of subcutaneous and abdominal adipose depot masses in Holstein cows with lower and higher body condition (mean body condition scores: 3.48 and 3.87, respectively) were compared in the period from $\mathrm{d}-42$ to $\mathrm{d} 70$ relative to parturition in this study. Animals of the 2 experimental groups represented adequately conditioned and overconditioned cows. Estimated depot mass (eDM) of SCAT, AAT, retroperitoneal, omental, and mesenteric adipose depots of 31 pluriparous German Holstein cows were determined via ultrasonography at $\mathrm{d}-42,7,28$, and 70 relative to parturition. The cows were grouped according to the eDM of SCAT on d -42 [low body condition (LBC) group: $\mathrm{n}=16$, mean eDM $8.6 \mathrm{~kg}$; high body condition (HBC) group: $\mathrm{n}=15$, mean eDM $15.6 \mathrm{~kg}$ ]. Average daily change (prepartum gain and postpartum loss) in depot masses during dry period (DP; from d -42 to d 7), FCP (d 7 to d 28), and ELP (d 28 to d 70) were calculated and daily dry matter intake and lactation performance recorded. Cows of this study stored about 2 to 3 times more fat in AAT than in SCAT depots. After parturition, on average more adipose tis-
\end{abstract}

Received September 21, 2019.

Accepted May 25, 2020.

*Current address: Institute for Animal Hygiene, Animal Welfare and Farm Animal Behavior, University of Veterinary Medicine Hannover, Foundation, Bischofsholer Damm 15, 30173 Hannover, Germany.

†Corresponding author: Juergen.Rehage@tiho-hannover.de sue mass was lost from the AAT than the SCAT depot $(0.23 \mathrm{~kg} / \mathrm{d}$ vs. $0.14 \mathrm{~kg} / \mathrm{d})$. Cows with high compared with low body condition had similar gains in AAT (0.33 $\mathrm{kg} / \mathrm{d})$ and SCAT $(0.14 \mathrm{~kg} / \mathrm{d})$ masses during the DP but mobilized significantly more adipose tissue mass from both depots after calving (AAT, HBC vs. LBC: 0.30 vs. $0.17 \mathrm{~kg} / \mathrm{d}$; SCAT, HBC vs. LBC: 0.19 vs. $0.10 \mathrm{~kg} / \mathrm{d}$ ). Correlation analysis indicated a functional disparity between AAT and SCAT. In the case of AAT $\left(\mathrm{R}^{2}=\right.$ 0.36 ), the higher the gain in adipose mass during DP, the higher the loss in FCP, but this was not the case for SCAT. During FCP, a greater NEB resulted in greater loss of mass from SCAT $\left(\mathrm{R}^{2}=0.18\right)$. In turn, greater mobilization of SCAT mass led to a higher calculated feed efficiency $\left(\mathrm{R}^{2}=0.18\right)$. However, AAT showed no such correlations. On the other hand, during ELP, loss of both SCAT and AAT mass correlated positively with feed efficiency $\left(\mathrm{R}^{2}=0.35\right.$ and 0.33 , respectively). The results indicate that feed efficiency may not be an adequate criterion for performance evaluation in cows during NEB. Greater knowledge of functional disparities between AAT and SCAT depots may improve our understanding of excessive lipomobilization and its consequences for metabolic health and performance of dairy cows during the transition period.

Key words: adipose tissue depot, lipomobilization, fresh cow period, activity, ultrasonography

\section{INTRODUCTION}

The fresh cow and early lactation periods are usually characterized by negative energy balance (NEB), which is a consequence of increased nutrient demand of milk production, and inadequate feed intake (Grummer, 1995). Body reserves, which play a key role in adaptation to energy deficit, are mobilized from subcutaneous (SCAT) and visceral adipose tissue depots to counterbalance the NEB (Roche et al., 2009). Previous studies established that dairy cows accumulate more 
fat in abdominal adipose tissues (AAT; Wright and Russel, 1984). Furthermore, recent studies using postmortem examinations suggest that SCAT and AAT may contribute differently to fat mobilization (von Soosten et al., 2011; Raschka et al., 2016). Additionally, functional differences between SCAT and retroperitoneal adipose tissue (RPAT), a subunit of AAT, have been reported. Retroperitoneal adipose tissue seems to have a higher lipolytic activity than SCAT in the first weeks after calving (Locher et al., 2011; Kabara et al., 2014; Saremi et al., 2014). Also in experimental animals and humans, remarkable disparities in functional properties of subcutaneous and visceral adipose tissues have been reported (Yang and Smith, 2007). Such functional disparities between SCAT and AAT may also have a significant influence on the development of metabolic health disorders in dairy cows, such as subclinical ketosis (SCK) and fatty liver (Roche et al., 2013), because nonesterified fatty acids (NEFA) released during lipolysis from AAT, but not from SCAT, are drained directly via the portal vein into the liver for further metabolism (Montague and O'Rahilly, 2000; Fiore et al., 2018).

Commonly, body condition, a ratio of adipose tissue to other components of the body, is either semiquantitatively assessed by visual scoring (BCS) or quantitatively assessed by ultrasonographic measurement of backfat thickness (Schröder and Staufenbiel, 2006; Roche et al., 2009, 2013). The disadvantage of these techniques is that they reflect only subcutaneous adipose depots. The AAT, mainly comprising RPAT, mesenteric adipose tissue (MAT), and omental adipose tissue (OMAT) depots, cannot be assessed by these methods (Roche et al., 2013). Recently Raschka et al. (2016) established and validated an ultrasonographic technique to estimate the mass of SCAT, RPAT, OMAT, MAT, and total AAT in vivo in German Holstein dairy cows. Similar techniques have also been reported for beef cattle (Kim et al., 1998; Ribeiro and Tedeschi, 2012), goats (Teixeira et al., 2008; Peres et al., 2010), and sheep (Ripoll et al., 2010). Using the ultrasonographic technique of Raschka et al. (2016), Ruda et al. (2019) studied Holstein dairy cows from day -42 before parturition to 100 DIM. The authors showed that the estimated depot mass (eDM) of AAT was about 2.5 times greater than that of SCAT and that, postpartum, absolutely and relatively more fat was mobilized from AAT compared with SCAT, supporting the previously mentioned molecular studies stating a higher lipolytic activity in visceral than subcutaneous adipose depots during this stage of lactation.
As a follow-up and confirmation study, the aim of present study was to compare the changes in mass of subcutaneous and abdominal adipose depots in cows with initially higher and lower body condition and the effects on energy metabolism and performance.

\section{MATERIALS AND METHODS}

Data for this study were retrieved from a previously published trial (Schäfers et al., 2017) on the effects of vitamin $\mathrm{E}$ and CLA on performance, lipomobilization, and energy metabolism in dairy cows from d 42 before until d 70 after parturition. The study was carried out at the experimental station of the Friedrich-LoefflerInstitute, Brunswick, Germany, in accordance with the German Animal Welfare Act, and was approved by the Lower Saxony State Office for Consumer Protection and Food Safety (LAVES, Oldenburg, Germany).

\section{Animals and Diets}

Schäfers et al. (2017) described the experimental design, feeds, diets, collection of samples, analytical procedures, ultrasonographic examinations, and recordings of performance data and their further processing in detail. Briefly, 64 pluriparous German Holstein cows were allocated into 4 groups ( $\mathrm{n}=16$ per group), 3 treatment groups (CLA, Vit $\mathbf{E}$, and $\mathbf{C L A}+$ Vit $\mathbf{E}$ ) and 1 control group. Cows were studied from d 42 prepartum until d 70 postpartum. Cows were fed ad libitum with a standardized partial mixed ration from self-feeding troughs (RIC, Insentec B.V., Marknesse, the Netherlands) during the trial. Additionally, the animals were supplied with $3 \mathrm{~kg} / \mathrm{d}$ per cow of concentrate by means of automated self-feeding stations (Insentec B.V.). The ration consisted of $60 \%$ concentrate and $40 \%$ silage $(50 \%$ corn, $50 \%$ grass silage on DM basis) from d -42 until parturition. After parturition, the portion of concentrate steadily increased from 30 to $50 \%$ until d 21 and then remained at this level until the end of the trial. The CLA group received a mix of CLA with a target to supply $8.4 \mathrm{~g}$ of cis-9,trans-11 and $8.4 \mathrm{~g}$ of trans-10, cis-12 per day per cow (BASF Lutrell, Lampertheim, Germany); the vitamin E group was treated with 2.327 IU of vitamin E per day per cow (BASF Lutavit E 50); and the CLA+Vit E group received both treatments. Because no significant effects of any treatment were found on mass of adipose tissues (Schäfers et al., 2017), the data set appeared generally suitable for further evaluation of gain and loss of adipose tissue masses during the transition period. 


\section{Selection of Cows, Ultrasonographic Examination, and Activity Measurements}

In total, 31 cows with BCS $>3.0$ were selected (CLA, Vit $\mathrm{E}$, and control groups: $\mathrm{n}=8$; CLA+Vit $\mathrm{E}$ group: $\mathrm{n}$ $=7$ ) for ultrasonographic assessment of SCAT, RPAT, OMAT, and MAT depot mass. Total abdominal depot mass was calculated as the sum of RPAT, OMAT, and MAT. Ultrasonographic measurements were performed on $\mathrm{d}-42$, $\mathrm{d} 7, \mathrm{~d} 21$, and $\mathrm{d} 70$ relative to parturition, according to Raschka et al. (2016). For ultrasonography, a Mindray M5 Vet (Mindray, Shenzhen, China) ultrasound system equipped with a convex $(3 \mathrm{MHz}$, Mindray $3 \mathrm{C} 5 \mathrm{~s})$ and a linear probe (6 MHz, Mindray 6LE5Vs) was used. Measurements were performed in duplicate without applying pressure, to avoid bias (Raschka et al., 2016). For statistical analysis, means of the 2 measurements were used.

Activity data were collected from the same 31 cows using IceTag accelerometers (IceTag 2.004, IceRobotics Ltd., South Queensferry, UK). The accelerometer technology can be used to survey lying, standing, and stepping performance of cattle and has been validated, showing high sensitivity and specificity for lying and standing behavior (Trénel et al., 2009; Nielsen et al., 2018). The device was attached on the lateral side of 1 hind leg above the fetlock by a hook-and-loop strap. With a recording frequency of $1 \mathrm{~s}$, the measurements were done in wk $-6,-2,3$, and 9 relative to parturition. Data were recorded for at least 3 consecutive days during each measurement period. The activity data were downloaded by using IceTagAnalyser software (version 2.009, IceRobotics Ltd.) and were exported to an Excel 2010 spreadsheet (Microsoft Corp., Redmond, WA). The activity data were used to determine lying time per day $(\mathrm{h} / \mathrm{d})$, lying bouts per day (no./d), and steps per day (no./d) and to calculate lying time per lying bout (min/bout). The data collection day was defined as starting at $1200 \mathrm{~h}$ and ending the following day at $1159 \mathrm{~h}$. Only lying phases of more than 2-min duration were considered. For statistical analysis, 3-d means of the respective activity variable for each recording period were used (Bewley et al., 2010).

\section{Performance Data, Diet, Blood, and Liver Samples}

Schäfers et al. (2017) described all methods in detail. Briefly, BCS was determined using the 5-point scale (Edmonson et al., 1989), scored by the same experienced researcher. Body weight was measured once a week before parturition and postpartum after each milking until d 70. Cows were milked twice a day at 0530 and $1530 \mathrm{~h}$. Milk yield was measured by automated milking stations (Lemmer Fullwood GmbH, Lohmar, Germany). Milk samples were collected twice a week for analysis of milk components (infrared milk analyzer Milkoscan FT 6000, Foss Electric, Hillerod, Denmark; fat, protein, lactose, and urea concentrations), of which only milk fat percentage is presented here.

Blood samples were taken after each morning milking on $\mathrm{d}-42,-14,-7,1,3,7,10,14,21,28,36,42,56$, and 70 relative to parturition from the jugular vein, for analysis of NEFA and BHB in serum via a photometric system (Eurolyser VET CCA, Salzburg, Austria). Samples of the partial mixed ration and concentrate collected twice and once weekly, respectively, were pooled for 4 -wk periods to a collective sample and analyzed according to the standard methods of VDLUFA (1993; DM, crude ash, CP, ether extract, crude fiber, and NDF; Schäfers et al., 2017).

\section{Calculations and Statistical Analysis}

The performance variables DMI, energy intake (EI), energy balance (EB), milk yield, and milk components were calculated as weekly means before statistical analysis. Equations used for calculation of EI, EB, FCM, ECM, and feed efficiency $(\mathbf{F E}, \mathrm{kg} / \mathrm{kg} ; \mathrm{FE}=\mathrm{ECM} /$ DMI) are presented by Schäfers et al. (2017). Results of statistical evaluation of milk lactose, protein, and urea content are presented in Supplemental Table S1 (https: //doi.org/10.3168/jds.2019-17623).

Ultrasonographic measurements were used to determine adipose tissue masses using the regression equations of Raschka et al. (2016): SCAT $=-6.66+0.72$ $\times \mathrm{R} 12+0.31 \times \mathrm{AW} 3 \mathrm{c} ; \mathrm{RPAT}=-9.55+0.62 \times \mathrm{R} 12$ $+0.06 \times$ KD3b; OMAT $=-2.32+0.55 \times \mathrm{BFT}+$ $0.37 \times \mathrm{AW} 3 \mathrm{~b}$ and MAT $=-12.8+0.38 \times \mathrm{AW} 1 \mathrm{~b}+$ $1.73 \times \mathrm{AW} 3 \mathrm{~b}-1.45 \times \mathrm{AW} 3 \mathrm{c}+0.07 \times \mathrm{KD} 2 \mathrm{c}$, where $\mathrm{R} 12=12$ th rib at the level of the greater trochanter; $\mathrm{AW} 1 \mathrm{~b}=$ point of interception of a vertical line through the last lumbar vertebra and a horizontal line through the greater trochanter of femur, from skin to end of musculature; AW3b and AW3c = center of the paralumbar fossa, b) from skin to end of musculature, c) from skin to peritoneum; KD2c $=$ intertransverse space cranial to lumbar intertransverse space where caudal pole of the right kidney is visible, measuring from skin to peritoneum; KD3b = intertransverse space cranial to KD2, measuring from skin to end of kidney; and BFT = backfat thickness according to Schröder and Staufenbiel (2006). The AAT mass was calculated as the sum of RPAT, MAT, and OMAT. For further details, see Schäfers et al. (2017). Average daily change in depot mass (aDC; $\mathrm{kg} / \mathrm{d})$ during the dry period (DP; from $\mathrm{d}-42$ to $\mathrm{d} 7$ relative to parturition), fresh cow period 
(FCP; from d 7 to d 28), and early lactation period (ELP; from d 28 to d 70) were calculated by dividing the difference of eDM at the end and beginning of each period by the number of the actual days of that timespan: aDC DP $=(\mathrm{eDM} d 7-\mathrm{eDM} d-42) / \mathrm{d} ; \mathrm{aDC} F C P$ $=(\mathrm{eDM} d 28-\mathrm{eDM} d 7) / \mathrm{d} ;$ and $\mathrm{aDC}$ ELP $=(\mathrm{eDM} \mathrm{d}$ $70-\mathrm{eDM} d \mathrm{28}) / \mathrm{d}$. The relative daily change in depot mass (rDC1) in percent of eDM at the beginning of each period $(\mathrm{rDC} 1=\mathrm{aDC} / \mathrm{eDM} \times 100)$ was calculated. In addition, the relative estimated average depot mass $(\mathbf{r D M})$ in percent of $\mathrm{BW}(\mathrm{rDM}=\mathrm{eDM} / \mathrm{BW} \times 100$; $\mathrm{BW}$ of corresponding measurement day) and the relative daily change in $\mathrm{eDM}(\mathbf{r D C 2})$ in percent of $\mathrm{BW}$ $(\mathrm{rDC} 2=\mathrm{aDC} / \mathrm{BW} \times 100 ; \mathrm{BW}$ at beginning of respective period) were determined.

To assign cows to the low body condition (LBC) or high body condition (HBC) group, cows were ranked according to the eDM SCAT on $\mathrm{d}-42$ before parturition. The 15 cows with highest eDM SCAT d -42 were assigned to $\mathrm{HBC}$ and 16 cows with the lowest eDM SCAT to the LBC group (from CLA, Vit E, CLA+Vit $\mathrm{E}$, and control groups, respectively, 3, 6, 2, and 4 cows in $\mathrm{HBC}$; and 5, 3, 4, and 4 cows in LBC). For calculation of the incidence of SCK (BHB >1.2 mmol/L; Leblanc, 2010; Ospina et al., 2010), each cow reaching the threshold in FCP or ELP was counted as 1 case. Cows considered already in FCP as subclinically ketotic were not counted as new cases in ELP when reaching the threshold again.

For statistical analyses, the SAS software package (version 9.3; SAS Institute Inc., Cary, NC) was used. The pre- and postpartum periods were analyzed separately, except for adipose tissue mass. The MIXED procedure for repeated measures with compound symmetry or antedependence covariate structure was used (Littell et al., 1998). Group, time, and their interaction were used as fixed effects, and cow within group was considered as a random effect. Repeated measures were the day, week, or period of sample collection. Animal identification was used as the SUBJECT option within the REPEATED statement, and the Tukey post hoc test was used for comparisons of corresponding means. Period mean of EB was calculated from weekly means of $\mathrm{EB}$ for $\mathrm{DP}$, and period means of $\mathrm{EB}$ and $\mathrm{FE}$ were calculated from corresponding weekly means for FCP and ELP. The MIXED procedure was also used to identify statistical differences in $\mathrm{eDM}$ and aDC means of SCAT and AAT over all cows (fixed effects: adipose depot, time, and their interaction; random effect: cow). For analysis of Pearson correlations, the PROC CORR procedure of SAS was used. Frequencies were tested by Fisher's exact test for statistical differences between groups using PROC FREQ of SAS. Effects were defined as trends when $P$-values were $0.05<P$ $\leq 0.10$, and as statistically significant when $P$-values were $P \leq 0.05$.

\section{RESULTS}

\section{Estimated Depot Mass of Adipose Tissues}

Comparing mean eDM of SCAT and AAT over all studied cows' results revealed a significantly higher depot mass for AAT than for SCAT throughout the study period (depot effect: $P<0.001$; time $\times$ depot effect: $P$ $=0.053$; Table 1$)$. The eDM of AAT was about 2 to 3 times larger than that of SCAT. In addition, the rDM, in percent of BW, throughout the study was higher in AAT than in SCAT (time, depot, and time $\times$ depot effects: $P<0.001$; Table 1). During DP, aDC of AAT was significantly higher and, during FCP and ELP, more negative compared with SCAT (Table 1; time effect: $P$ $<0.001$; depot: $P=0.84$; time $\times$ depot: $P<0.001$ ). The results were similar when the aDC was calculated as percent of $\mathrm{BW}$ (rDC2; time effect: $P<0.001$; group: $P=0.89$; group $\times$ time: $P<0.001)$. However, when calculating aDC as percent of eDM ( $\mathrm{rDC} 1)$, relatively more fat was mobilized from SCAT than from AAT (time effect: $P<0.001$; group: $P=0.14$; group $\times$ time: $P=0.030 ;$ Table 1$)$.

Results of eDM for SCAT (time: $P<0.001$; group: $P<0.001 ;$ time $\times$ group: $P=0.003)$ and for AAT (time: $P<0.001$; group: $P<0.001$; time $\times$ group: $P$ $=0.005)$ revealed significant time effects on depot and group differences between cows of the HBC and LBC groups (Table 2). This group difference, also found on d 7, disappeared on d 28 and d 70 after parturition. In both groups, cows gained, on average, about $140 \mathrm{~g} / \mathrm{d}$ of depot mass in SCAT and about $330 \mathrm{~g} / \mathrm{d}$ in AAT during the DP (Table 2). After parturition, cows in the HBC group lost, on average, more SCAT and AAT than the LBC group did (time effects: $P<0.001$; group effect for SCAT: $P=0.005$; and group effect for AAT: $P=$ 0.008). In ELP, the aDC of AAT was still significantly higher in the HBC compared with the LBC group ( $P$ $<0.05$; Table 2).

As for eDM for AAT, statistical evaluation of mean eDM of abdominal subunit depots of RPAT, OMAT, and MAT revealed significant time $(P<0.01)$ and group effects $(P<0.01)$, with higher mean eDM in the HBC group than in the LBC group (Table 3 ). A time $\times$ group effect existed for $\operatorname{RPAT}(P=0.024)$ and OMAT $(P<0.001)$. Mean aDC during DP of all 3 subunit depots did not differ significantly between groups. After parturition, on average, aDC was more negative in HBC compared with LBC cows for RPAT and OMAT depots (group effects: $P=0.039$ and $P<$ 0.001 , respectively). 
Table 1. Adipose tissue depot mass for subcutaneous adipose tissue (SCAT) and total abdominal adipose tissue (AAT) of all experimental German Holstein cows in the study (LSM; $\mathrm{n}=31$ )

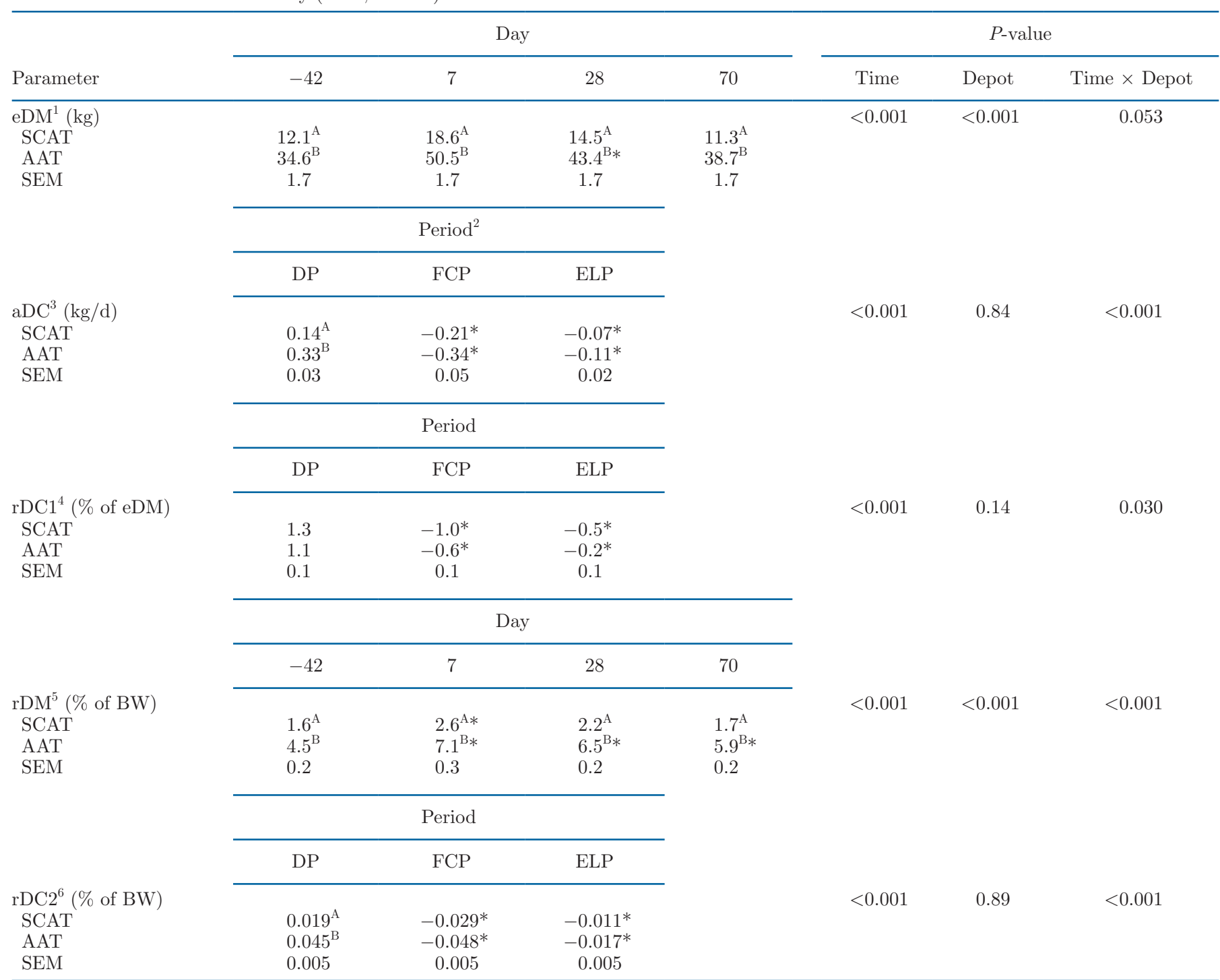

$\overline{\mathrm{A}, \mathrm{B}}$ Corresponding means within a column with different superscripts differ $(P<0.05)$.

${ }^{1} \mathrm{eDM}=$ estimated average depot mass, sonographically estimated, during the transition period (day relative to parturition).

${ }^{2} \mathrm{DP}=$ dry period $(\mathrm{d}-42$ to 7 relative to parturition); FCP $=$ fresh cow period (d 7 to 28 postpartum); ELP = early lactation period (d 28 to 70 postpartum).

${ }^{3} \mathrm{aDC}=$ average daily change in depot mass, by period.

${ }^{4} \mathrm{rDC} 1$ = relative daily change in depot mass, in percent of eDM of corresponding depot mass at the beginning of each period; $\mathrm{rDC} 1=\mathrm{aDC} /$ $\mathrm{eDM} \times 100$.

${ }^{5} \mathrm{rDM}=$ relative estimated average depot mass, in percent of $\mathrm{BW}$ at day of eDM measurement; $\mathrm{rDM}=\mathrm{eDM} / \mathrm{BW} \times 100$.

${ }^{6} \mathrm{rDC} 2=$ relative daily change in estimated depot mass, in percent of $\mathrm{BW}$ at the beginning of each period; $\mathrm{rDC} 2=\mathrm{aDC} / \mathrm{BW} \times 100$.

*Means within a row differ from baseline within group $(P<0.05)$.

Significant time and group effects were found for the relative daily change of depot mass in percent of $\mathrm{eDM}(\mathrm{rDC} 1)$ for $\operatorname{SCAT}(P<0.001$ and $P=0.002$, respectively) and $\operatorname{AAT}(P<0.001$ and $P=0.002$, respectively; Table 4). During DP, on average, HBC cows gained numerically less fat in SCAT and AAT compared with LBC cows, but HBC cows lost as much or even more fat mass during FCP and ELP. Cows of the HBC compared with the LBC group presented, on average throughout the study period, a higher relative depot mass in percent of BW (rDM; Supplemental Table S2, https://doi.org/10.3168/jds.2019-17623) for 
Table 2. Average depot masses of subcutaneous adipose tissue (SCAT) and total abdominal adipose tissue (AAT) for German Holstein cows with low body condition (low SCAT mass on $\mathrm{d}-42$ relative to calving, $\mathrm{n}=16$ ) and high body condition (high SCAT mass on $\mathrm{d}-42$ relative to calving, $\mathrm{n}=15)$; LSM

\begin{tabular}{|c|c|c|c|c|c|c|c|}
\hline Parameter & \multicolumn{4}{|c|}{ Day } & \multicolumn{3}{|c|}{$P$-value } \\
\hline \multicolumn{8}{|l|}{$\overline{\mathrm{eDM}^{1}(\mathrm{~kg})}$} \\
\hline Low & $8.6^{\mathrm{A}}$ & $15.1^{\mathrm{A} *}$ & $12.2^{*}$ & $10.1^{*}$ & & & \\
\hline High & $15.8^{\mathrm{B}}$ & $22.7^{\mathrm{B} *}$ & 16.9 & 12.7 & & & \\
\hline SEM & 0.9 & 1.5 & 1.4 & 1.2 & & & \\
\hline \multirow[t]{3}{*}{ SEM } & 1.8 & 3.3 & 2.5 & 2.5 & & & \\
\hline & \multicolumn{3}{|c|}{ Period $^{2}$} & & & & \\
\hline & DP & FCP & ELP & & & & \\
\hline \multicolumn{8}{|l|}{$\mathrm{aDC}^{3}(\mathrm{~kg} / \mathrm{d})$} \\
\hline \multicolumn{5}{|l|}{ AAT } & $<0.001$ & 0.008 & 0.15 \\
\hline Low & 0.34 & $-0.30^{*}$ & $-0.03^{\mathrm{A} *}$ & & & & \\
\hline High & 0.31 & $-0.38^{*}$ & $-0.21^{\mathrm{B} *}$ & & & & \\
\hline SEM & 0.06 & 0.09 & 0.04 & & & & \\
\hline
\end{tabular}

SCAT and AAT (time and group effects: $P<0.001$ group: $P<0.001)$. According to Supplemental Table S3 (https://doi.org/10.3168/jds.2019-17623), the relative daily change in eDM in percent of $\mathrm{BW}$ ( $\mathrm{rDC} 2$ ) revealed statistically significant time and group effects for SCAT $(P<0.001$ and $P=0.016$, respectively) and a significant time effect for AAT (time: $P<0.001$; group effect: $P=0.070$ ). During DP, HBC cows showed almost same relative gain ( $\mathrm{rDC} 2)$ but more relative loss during FCP and ELP for SCAT and AAT compared with LBC cows.

Similar results were found for relative depot masses of the 3 abdominal subunit depots, except for the group effect of RPAT, which was not significant (Supplemental Table S2). In both groups, the 3 abdominal depots gained eDM to the same extent during the DP. After parturition, more fat was lost from RPAT (group effect: $P=0.039$ ) and OMAT (group effect: $P<0.001$ ) in the HBC group compared with the LBC group, but no group effects were found for MAT. These findings were almost in accordance with the relative daily changes of the different fat depots (Table 4 and Supplemental Table S3).

\section{Body Weight and Performance}

Significant time effects $(P<0.001)$ were found for BW, BCS, DMI, EI, and EB before and after parturition and for milk yield, milk fat content, FCM, ECM, and FE postpartum (Table 5). The BCS of the LBC and HBC groups were 3.48 and $3.87 \pm 0.09$ (mean \pm SEM), respectively. Mean BCS (group effect: $P=$ 0.027 ) and BW (group effect: $P<0.001$ ) increased during DP and were significantly higher in the HBC than in the LBC group. The DMI, EI, and EB decreased starting about 3 to 2 wk before parturition, particularly EB in the HBC group (group $\times$ time effect: $P$ $=0.005)$. Postpartum mean BW and BCS decreased continuously. However, the average loss was greater in the HBC than in the LBC group (BW group effect: $P=0.002$; BW group $\times$ time effect: $P=0.025$; BCS group effect: $P=0.013$; BCS group $\times$ time effect data 
not significant: $P=0.52$ ). Results revealed no further group $\times$ time effects for any parameter and no group effects for DMI, EI, or milk yield postpartum. The milk fat content (group effect: $P=0.005$ ), FCM (group effect: $P<0.001$ ), ECM (group effect: $P<0.001$ ), and FE (group effect: $P=0.004$ ) were significantly higher and $\mathrm{EB}$ (group effect: $P<0.001$ ) significantly lower in the HBC compared with the LBC group.

\section{Activity Parameter}

Postpartum activity recordings revealed no significant time, group, or time $\times$ group effects (Table 6 ). Although from wk 6 to wk 2 before parturition, the number of lying bouts per day increased (time effect: $P=0.004$ ), the lying time per bout decreased (time effect: $P=0.008)$. Cows of the HBC group presented on average a greater number of lying bouts per day (group effect: $P=0.041$ ) but lower lying time per bout (group effect: $P=0.023$ ) and fewer steps per $24 \mathrm{~h}$ (group effect: $P=0.005)$ compared with the LBC group.

\section{Blood NEFA and BHB}

Mean blood concentrations of NEFA increased slightly during the DP (time effect: $P=0.049$; Table 7 ). Concentrations of BHB were significantly higher in the HBC than in the LBC group in the DP (group effect: $P$

Table 3. Average depot masses of abdominal adipose tissues ${ }^{1}$ for German Holstein cows with low body condition (low subcutaneous adipose tissue mass on $\mathrm{d}-42$ relative to calving, $\mathrm{n}=16$ ) and high body condition (high subcutaneous adipose tissue mass on $\mathrm{d}-42$ relative to calving, $\mathrm{n}=15$ ); LSM

\begin{tabular}{|c|c|c|c|c|c|c|c|}
\hline \multirow[b]{2}{*}{ Parameter } & \multicolumn{4}{|c|}{ Day } & \multicolumn{3}{|c|}{$P$-value } \\
\hline & -42 & 7 & 28 & 70 & Time & Group & Time $\times$ Group \\
\hline \multicolumn{8}{|l|}{$\overline{\mathrm{eDM}^{2}(\mathrm{~kg})}$} \\
\hline RPAT & & & & & $<0.001$ & 0.001 & 0.024 \\
\hline Low & $6.2^{\mathrm{A}}$ & $9.3^{\mathrm{A}}$ & 7.9 & 7.3 & & & \\
\hline High & $10.5^{\mathrm{B}}$ & $15.1^{\mathrm{B} *}$ & 11.9 & 9.1 & & & \\
\hline SEM & 0.7 & 1.1 & 0.9 & 0.7 & & & \\
\hline OMAT & & & & & $<0.001$ & $<0.001$ & $<0.001$ \\
\hline Low & $9.1^{\mathrm{A}}$ & $17.2^{\mathrm{A} *}$ & $14.6^{*}$ & $12.8^{*}$ & & & \\
\hline High & $16.4^{\mathrm{B}}$ & $24.4^{\mathrm{B} *}$ & 19.0 & 13.9 & & & \\
\hline SEM & 0.9 & 1.4 & 1.1 & 1.0 & & & \\
\hline MAT & & & & & 0.006 & $<0.001$ & 0.11 \\
\hline Low & $11.1^{\mathrm{A}}$ & $16.5^{*}$ & $14.3^{\mathrm{A}}$ & $15.6^{*}$ & & & \\
\hline High & $16.6^{\mathrm{B}}$ & 19.6 & $19.6^{\mathrm{B}}$ & 18.8 & & & \\
\hline \multirow[t]{3}{*}{ SEM } & 1.1 & 1.2 & 0.9 & 0.9 & & & \\
\hline & \multicolumn{3}{|c|}{ Period $^{3}$} & & & & \\
\hline & DP & FCP & ELP & & & & \\
\hline \multicolumn{8}{|l|}{$\mathrm{aDC}^{4}(\mathrm{~kg} / \mathrm{d})$} \\
\hline RPAT & & & & & $<0.001$ & 0.039 & 0.23 \\
\hline Low & 0.06 & -0.06 & -0.01 & & & & \\
\hline High & 0.08 & $-0.13^{*}$ & $-0.07^{*}$ & & & & \\
\hline SEM & 0.02 & 0.04 & 0.01 & & & & \\
\hline OMAT & & & & & $<0.001$ & $<0.001$ & 0.70 \\
\hline Low & 0.16 & $-0.12^{*}$ & $-0.04^{\mathrm{A} *}$ & & & & \\
\hline High & 0.13 & $-0.21^{*}$ & $-0.12^{\mathrm{B} *}$ & & & & \\
\hline SEM & 0.04 & 0.04 & 0.02 & & & & \\
\hline MAT & & & & & 0.028 & 0.91 & 0.11 \\
\hline Low & 0.11 & -0.11 & 0.03 & & & & \\
\hline High & 0.03 & 0.02 & -0.02 & & & & \\
\hline SEM & 0.03 & 0.05 & 0.02 & & & & \\
\hline
\end{tabular}

${ }^{\mathrm{A}, \mathrm{B}}$ Corresponding means within a column with different superscripts differ $(P<0.05)$.

${ }^{1} \mathrm{RPAT}=$ retroperitoneal adipose tissue $; \mathrm{OMAT}=$ omental adipose tissue; $\mathrm{MAT}=$ mesenteric adipose tissue.

${ }^{2} \mathrm{eDM}=$ estimated average depot mass, sonographically estimated, during the transition period (day relative to parturition).

${ }^{3} \mathrm{DP}=$ dry period $(\mathrm{d}-42$ to 7 relative to parturition); FCP $=$ fresh cow period (d 7 to 28 postpartum); ELP $=$ early lactation period (d 28 to 70 postpartum).

${ }^{4} \mathrm{aDC}=$ average daily change in depot mass, by period.

* Means within a row differ from baseline within group $(P<0.05)$. 
$=0.027)$. After parturition, mean blood NEFA concentrations increased significantly during the first $10 \mathrm{~d}$ and then decreased (time effect: $P<0.001$ ). Higher NEFA concentrations in the HBC compared with the LBC group (group effect: $P=0.039$ ) were found. No group or time $\times$ group effects were seen for blood concentrations of BHB postpartum. Mean blood BHB concentrations increased postpartum until $\mathrm{d} 28$ and then decreased again (time effect: $P=0.008$ ). No statistical differences were found in the incidence of SCK in FCP or ELP between groups [FCP: LBC, $\mathrm{n}=8 / 16(50 \%), \mathrm{HBC}, \mathrm{n}$ $=9 / 15(60 \%)$; ELP: LBC, $\mathrm{n}=1 / 16(6 \%)$, HBC, $\mathrm{n}=$ $2 / 15(13 \%)]$.

\section{Correlations Between Subcutaneous and Abdominal Adipose Depots, Energy Metabolism, and Performance}

The eDM at $\mathrm{d} 7$ postpartum of all assessed fat depots correlated significantly with the aDC of these depots in FCP and in ELP, except eDM of MAT in ELP (Table 8; range of $\mathrm{r}$ : -0.40 to -0.75$)$. The aDC during the DP of the AAT but not of the SCAT depot correlated significantly with the aDC during the FCP (range of r: -0.43 to -0.80 ) but not during the ELP, except for MAT. The aDC of SCAT and the abdominal fat depots RPAT and OMAT during FCP correlated significantly with blood concentrations of NEFA (range of $\mathrm{r}$ : -0.37 to -0.53 ), but no significant correlations were found with blood concentrations of $\mathrm{BHB}$, except for $\mathrm{FCP}$ aDC of MAT with BHB on d 7. The aDC of SCAT and OMAT in FCP showed a low but significant correlation with milk fat content in wk 2 and wk 3 and a trend in wk 4 (range of $\mathrm{r}$ : -0.34 to -0.43 ). Mean EB in the DP correlated significantly with aDC of SCAT in DP $(\mathrm{r}=$ $0.41 ; P=0.023)$ but not with aDC of AAT in the DP ( $\mathrm{r}=0.23 ; P=0.21$; Supplemental Figure S1, https:// doi.org/10.3168/jds.2019-17623).

In the FCP, a significant relationship between EB and aDC of SCAT (Figure 1a; $\mathrm{r}=0.42 ; P<0.05$ ) but not aDC of AAT (Figure 1b) was found. In the ELP, EB correlated significantly with aDC of SCAT (Figure $1 \mathrm{c} ; \mathrm{r}=0.60 ; P<0.001$ ) and aDC of AAT (Figure 1d; $\mathrm{r}=0.57 ; P<0.001)$. Figure 2 shows the relationship of aDC of SCAT in FCP (Figure 2a; $\mathrm{r}=-0.43 ; P<$ 0.05 ), aDC of AAT in FCP (Figure $2 \mathrm{~b}$; not significant; $r$

Table 4. Relative daily change in depot mass (rDC1) of subcutaneous and abdominal adipose tissue depots, by period, of German Holstein cows with low body condition (low subcutaneous adipose tissue mass on day -42 relative to calving, $\mathrm{n}=16$ ) and high body condition (high subcutaneous adipose tissue mass on $\mathrm{d}-42$ relative to calving, $\mathrm{n}=15) ; \mathrm{LSM}^{1}$

\begin{tabular}{|c|c|c|c|c|c|c|}
\hline \multirow{2}{*}{$\begin{array}{l}\text { rDC1 } \\
(\% \text { of eDM) }\end{array}$} & \multicolumn{3}{|c|}{ Period $^{2}$} & \multicolumn{3}{|c|}{$P$-value } \\
\hline & $\mathrm{DP}$ & $\mathrm{FCP}$ & ELP & Time & Group & Time $\times$ Group \\
\hline SCAT & & & & $<0.001$ & 0.002 & 0.37 \\
\hline Low & 1.7 & $-0.8^{*}$ & $-0.4^{*}$ & & & \\
\hline High & 1.0 & $-1.2^{*}$ & $-0.6^{*}$ & & & \\
\hline SEM & 0.2 & 0.2 & 0.1 & & & \\
\hline AAT & & & & $<0.001$ & 0.002 & 0.32 \\
\hline Low & 1.4 & $-0.6^{*}$ & $-0.1^{*}$ & & & \\
\hline High & 0.7 & $-0.6^{*}$ & $-0.4^{*}$ & & & \\
\hline SEM & 0.2 & 0.2 & 0.1 & & & \\
\hline RPAT & & & & $<0.001$ & 0.018 & 0.66 \\
\hline Low & 1.1 & $-0.6^{*}$ & 0.2 & & & \\
\hline High & 0.9 & $-0.7^{*}$ & -0.6 & & & \\
\hline SEM & 0.3 & 0.3 & 0.3 & & & \\
\hline OMAT & & & & $<0.001$ & $<0.001$ & 0.29 \\
\hline Low & 1.8 & $-0.6^{*}$ & $-0.3^{*}$ & & & \\
\hline High & 0.9 & $-0.9^{*}$ & $-0.6^{*}$ & & & \\
\hline SEM & 0.2 & 0.1 & 0.1 & & & \\
\hline MAT & & & & 0.05 & 0.31 & 0.07 \\
\hline Low & 1.5 & $-0.6^{*}$ & 0.3 & & & \\
\hline High & 0.3 & 0.4 & -0.1 & & & \\
\hline SEM & 0.4 & 0.4 & 0.1 & & & \\
\hline
\end{tabular}

${ }^{1} \mathrm{rDC} 1$ = average daily change in depot mass/estimated average depot mass (eDM) at the beginning of each period $\times 100$. SCAT $=$ subcutaneous adipose tissue; $\mathrm{AAT}=$ total abdominal adipose tissue; $\mathrm{RPAT}=$ retroperitoneal adipose tissue; OMAT $=$ omental adipose tissue; MAT $=$ mesenteric adipose tissue.

${ }^{2} \mathrm{DP}=$ dry period $(\mathrm{d}-42$ to 7 relative to parturition $) ; \mathrm{FCP}=$ fresh cow period (d 7 to 28 postpartum); ELP $=$ early lactation period (d 28 to 70 postpartum).

* Means within a row differ from baseline within group $(P<0.05)$. 
$=-0,09, P>0.1$ ), aDC of SCAT in ELP (Figure 2c; $\mathrm{r}$ $=-0.59 ; P<0.001$ ), and aDC of AAT in ELP (Figure $2 \mathrm{~d} ; \mathrm{r}=-0.58 ; P<0.001)$ with $\mathrm{FE}$ in FCP and ELP, respectively.

\section{DISCUSSION}

Cows in the current study were classified into the $\mathrm{HBC}$ and LBC groups according to the ultrasonographically measured eDM of SCAT 6 wk before parturition (d -42). Raschka et al. (2016) and Ruda et al. (2019) showed that ultrasonographic assessments are a sufficiently accurate tool to estimate in vivo subcutaneous and abdominal adipose depot masses and to follow their changes during the transition period. The technique contrasts with assessment of BCS or backfat thickness (Schröder and Staufenbiel, 2006; Roche et al., 2009) not only as an indicator of body condition. It provides a quantitative estimate of depot mass at repeated preset time points and thereby allows estimation of quantitative changes in depot mass between these time points, which reflect either mass gain during DP or mobilization of tissue after parturition. This study is based on a data set previously published by Schäfers et al. (2017), who enrolled only cows with a BCS of 3.0 or higher at the beginning of DP. Accordingly, cows of the "low" body condition group presented here represent not low but adequate BCS at the beginning of the study, whereas cows of the HBC group tended to an overconditioned state (Edmonson et al., 1989; Roche et al., 2009). The 2 groups differed significantly in mean BCS, $\mathrm{BW}$, and eDM of SCAT and AAT upon enrollment in the study. However, when classifying cows by eDM of SCAT at the time of study enrollment, it was expected that not only mean eDM of SCAT but also BW and BCS would differ significantly between groups at this time point. This continued throughout the DP, but the difference between HBC and LBC group means of these parameters disappeared with progression of lactation.

The ultrasonographically assessed eDM of SCAT and AAT and its subunit depots (RPAT, OMAT, and MAT) revealed the expected dynamics during the transition period of dairy cows, with gain during the DP, when mean EB is positive, and mobilization (loss) of fat after parturition, when EB is negative. At d 7, mean $\mathrm{eDM}$ of AAT and SCAT were about 50 and $19 \mathrm{~kg}$, respectively, which is in excellent accord with Ruda et al. (2019), who reported for AAT $52 \mathrm{~kg}$ and for SCAT $19 \mathrm{~kg}$ of depot mass $3 \mathrm{~d}$ postpartum, using almost the same ultrasonographic method for assessment of depot mass of adipose tissues. A greater depot mass of AAT compared with SCAT was also reported by von Soosten et al. (2011) and Raschka et al. (2016) based on post-

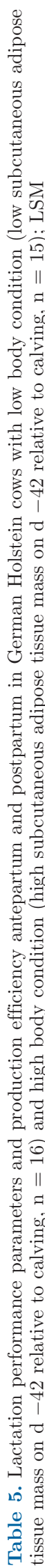

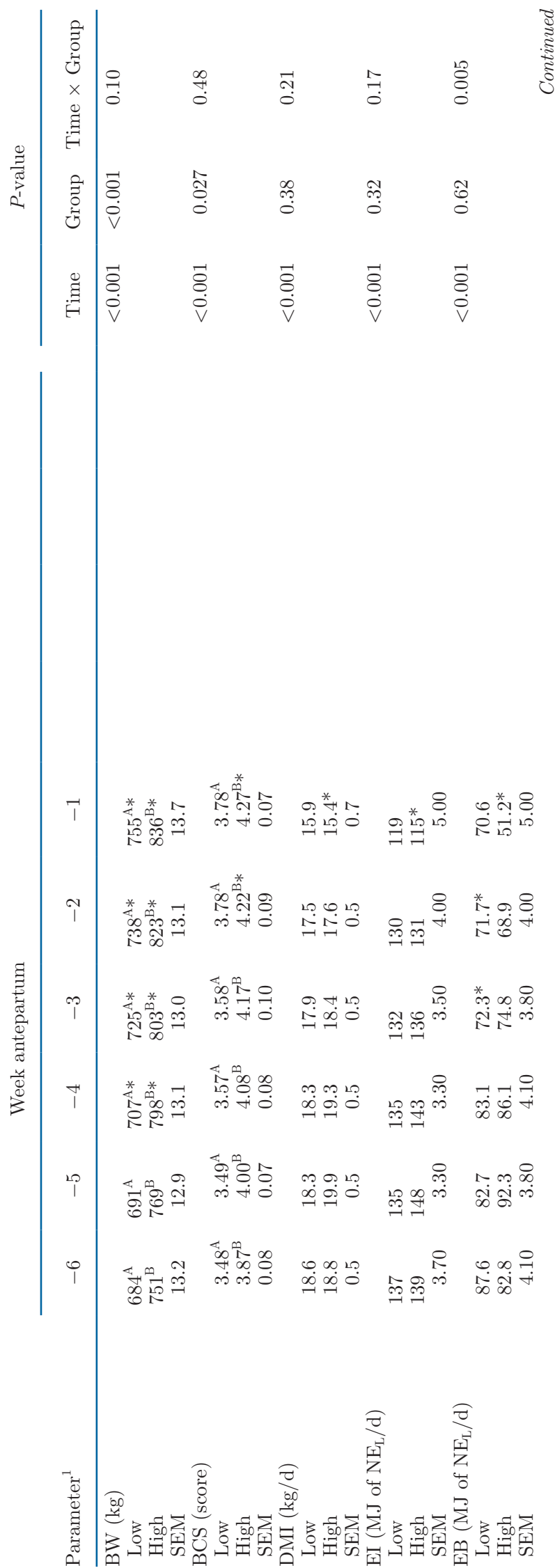


Szura et al.: ADIPOSE DEPOTS IN DAIRY COWS

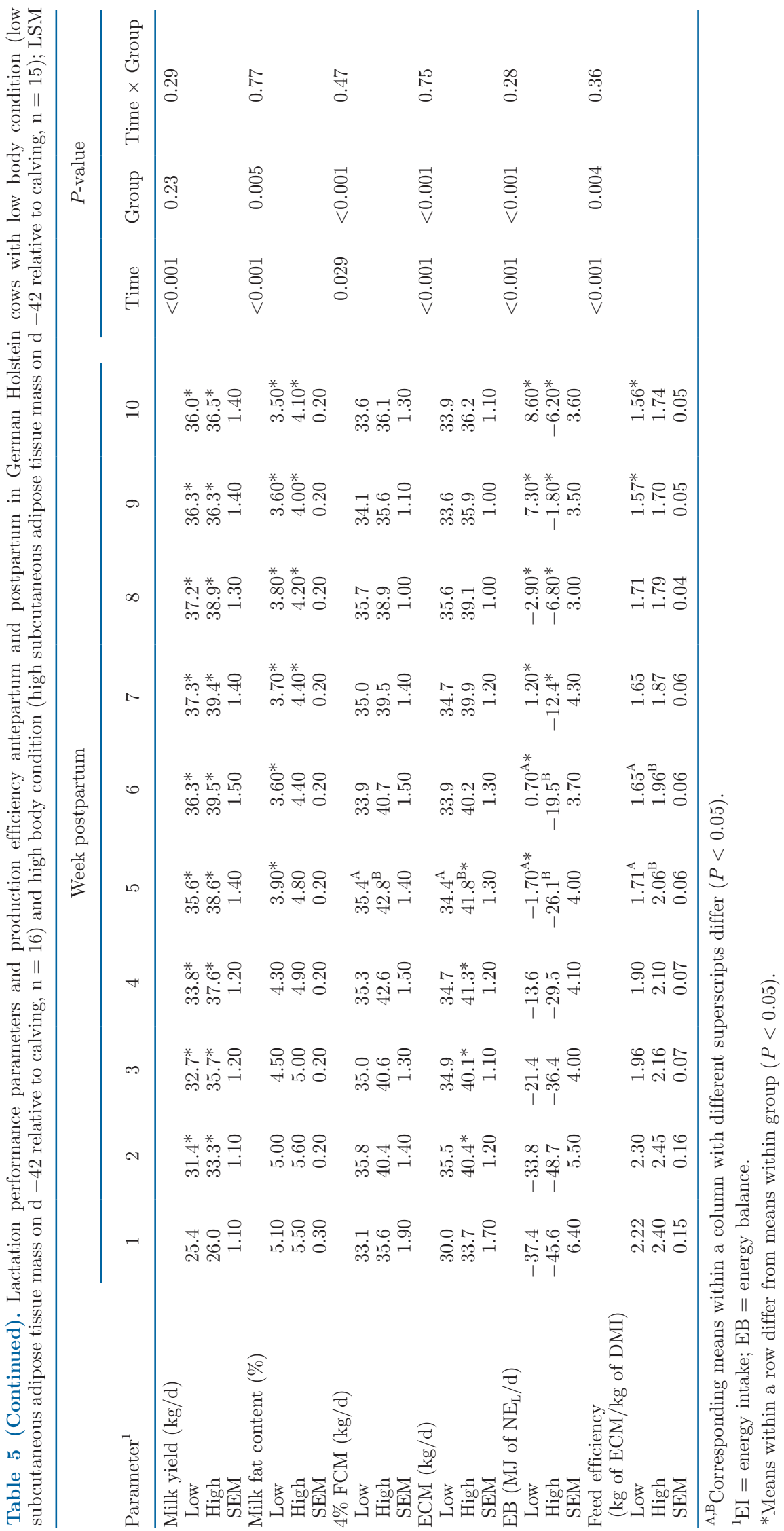


Szura et al.: ADIPOSE DEPOTS IN DAIRY COWS
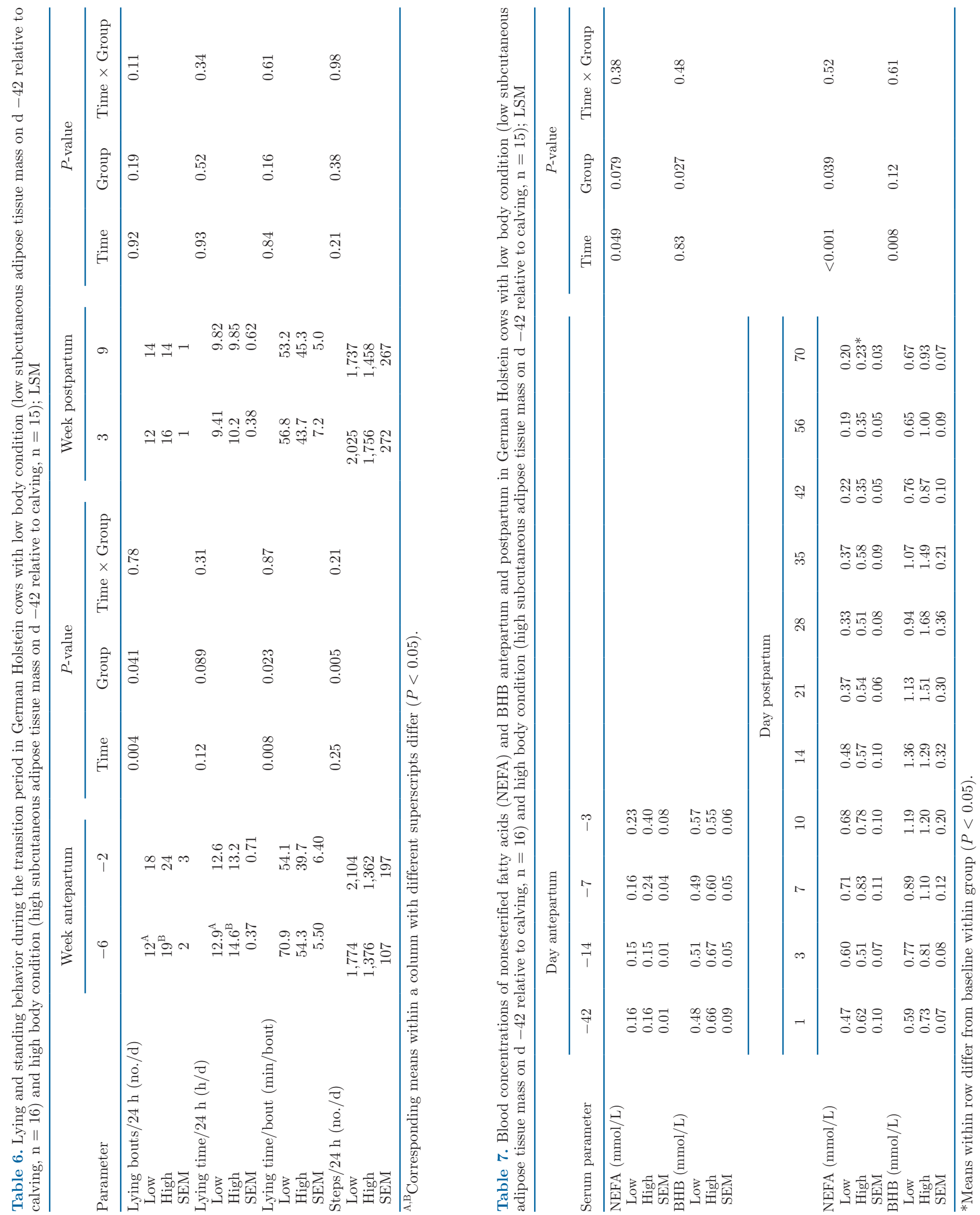
Table 8. Pearson correlations of estimated depot mass at parturition (eDM d 7) and average daily change in depot mass (aDC) of adipose tissue depots ${ }^{1}$ of German Holstein cows during fresh cow period (FCP) and early lactation period (ELP), with blood concentrations of nonesterified fatty acids (NEFA) and BHB and milk fat percentage postpartum

\begin{tabular}{llc}
\hline Item & FCP aDC & ELP aDC \\
\hline eDM d 7 & & \\
SCAT & $-0.49^{* *}$ & $-0.52^{* *}$ \\
AAT & $-0.62^{* * *}$ & $-0.40^{* *}$ \\
RPAT & $-0.60^{* * *}$ & $-0.48^{* *}$ \\
OMAT & $-0.75^{* * *}$ & $-0.55^{* *}$ \\
MAT & $-0.53^{* * *}$ & -0.07 \\
aDC DP & & -0.21 \\
SCAT & -0.23 & -0.01 \\
AAT & $-0.60^{* * *}$ & -0.16 \\
RPAT & $-0.43^{*}$ & 0.26 \\
OMAT & $-0.52^{* *}$ & $0.36^{*}$ \\
MAT & $-0.80^{* * *}$ & \\
& &
\end{tabular}

\begin{tabular}{lcccc} 
& \multicolumn{4}{c}{ Blood NEFA } \\
\cline { 2 - 5 } & $\mathrm{d} 7$ & $\mathrm{~d} 14$ & $\mathrm{~d} 21$ & $\mathrm{~d} 28$ \\
\cline { 2 - 5 } aDC FCP & & & & \\
SCAT & $-0.49^{* *}$ & -0.29 & $-0.37^{*}$ & $-0.41^{*}$ \\
AAT & $-0.38^{*}$ & -0.28 & 0.30 & -0.29 \\
RPAT & $-0.53^{* *}$ & $-0.40^{*}$ & $-0.37^{*}$ & $-0.42^{*}$ \\
OMAT & $-0.45^{*}$ & $-0.37 \dagger$ & $-0.41^{*}$ & $-0.47^{* *}$ \\
MAT & 0.06 & 0.06 & 0.02 & 0.13 \\
& & & & \\
\hline
\end{tabular}

Blood BHB

\begin{tabular}{lrccc}
\cline { 2 - 5 } & $\mathrm{d} 7$ & $\mathrm{~d} 14$ & $\mathrm{~d} 21$ & $\mathrm{~d} 28$ \\
\cline { 2 - 5 } SCAT & -0.06 & -0.19 & -0.22 & -0.28 \\
AAT & 0.30 & -0.22 & -0.15 & -0.17 \\
RPAT & -0.09 & $-0.33 \dagger$ & -0.22 & -0.26 \\
OMAT & 0.06 & -0.22 & -0.23 & $-0.31 \dagger$ \\
MAT & $0.59^{* *}$ & 0.02 & 0.06 & 0.13 \\
& & & & \\
\hline
\end{tabular}

\begin{tabular}{lrccc} 
& \multicolumn{4}{c}{ Milk fat \% } \\
\cline { 2 - 5 } & wk 1 & wk 2 & wk 3 & wk 4 \\
\cline { 2 - 5 } SCAT & -0.30 & $-0.38^{*}$ & $-0.52^{* *}$ & $-0.34 \dagger$ \\
AAT & 0.21 & -0.15 & -0.12 & -0.16 \\
RPAT & -0.07 & -0.26 & $-0.33 \dagger$ & -0.18 \\
OMAT & -0.02 & $-0.43^{*}$ & $-0.39^{*}$ & $-0.34 \dagger$ \\
MAT & $0.42^{*}$ & 0.23 & 0.29 & 0.10
\end{tabular}

${ }^{1} \mathrm{SCAT}=$ subcutaneous adipose tissue; AAT $=$ total abdominal adipose tissue; $\mathrm{RPAT}=$ retroperitoneal adipose tissue; OMAT $=$ omental adipose tissue; MAT $=$ mesenteric adipose tissue.

${ }^{2} \mathrm{DP}=$ dry period.

$\dagger P<0.1,{ }^{*} P<0.05,{ }^{* *} P<0.01,{ }^{* * *} P<0.001$.

mortem examination of German Holstein heifers and cows, respectively.

The DP, usually starting 6 to 8 wk before parturition, serves to restore cows' condition before the next lactation (van Knegsel et al., 2013). In the current study, more adipose tissue mass was gained in abdominal depots (about $330 \mathrm{~g} / \mathrm{d}$ ) than in SCAT (about 140 $\mathrm{g} / \mathrm{d}$ ). Gain of SCAT and AAT in the DP were within the range previously reported by Ruda et al. (2019). In this study, the relative mass ( $\mathrm{rDM}$ ) and the relative mass gain in percentage of $\mathrm{BW}$ ( $\mathrm{rDC} 2$ ) of AAT during the DP were also significantly higher compared with SCAT. However, as in the study of Ruda et al. (2019), mean $\mathrm{rDC} 1$, which is related to depot mass, revealed no significant differences between AAT and SCAT. Thus, results do not indicate a relatively higher accretion of fat during the DP in AAT compared with SCAT. The higher depot mass gain in AAT appears mainly due to a generally larger depot size than in SCAT.

During the DP, no significant differences were found in gain of abdominal and subcutaneous depot mass between the HBC and LBC groups. Because AAT depot mass was greater, rDC1 of AAT was numerically even lower than that of SCAT. Cows of both groups did not differ in DMI, EI, and EB during the DP, which may explain the lack of difference in gain between groups in this study. On average, cows of the HBC group tended to spend more time lying during the day and showed significantly less activity when standing, as indicated by the recorded number of steps in $24 \mathrm{~h}$, compared with the LBC group during DP. However, the mean number of lying bouts in $24 \mathrm{~h}$ was significantly higher in the HBC group than in the LBC group, and, in consequence, the lying time per bout was shorter. The spared energy expenditure caused by less activity while standing and longer lying time per day may have been superseded by more energy necessary for rising and lying down. At least possible differences in energy expenditure for activity did not result in measurably more adipose tissue stored in SCAT or AAT in HBC compared with LBC cows during the DP.

Activity is also an important indicator of animal welfare and comfort (Haley et al., 2001; Vasseur et al., 2012). Total daily lying time is the most commonly used trait, but the number and duration of lying bouts are also useful measures of welfare (Fregonesi and Leaver, 2001). Changes in behavioral traits may reflect discomfort experienced by cows, as well as the ease with which they can lie down, change lying position, and stand up (Vasseur et al., 2012; Shepley et al., 2019). Body condition can have an effect on the daily lying time, as well (Westin et al., 2016). Thus, it is possible that, due to higher body mass, cows in the HBC group experienced less comfort during lying than did LBC cows, and thus switched more often between lying and standing positions.

After calving, dairy cows, in particular cows with $\mathrm{HBC}$ at the time of calving, mobilize fat from adipose tissues to compensate for NEB (Schröder and Staufenbiel, 2006; Roche et al., 2009; Contreras et al., 2018). Accordingly, in the FCP, immediately after calving, when EB is more negative than in the ELP, in both 

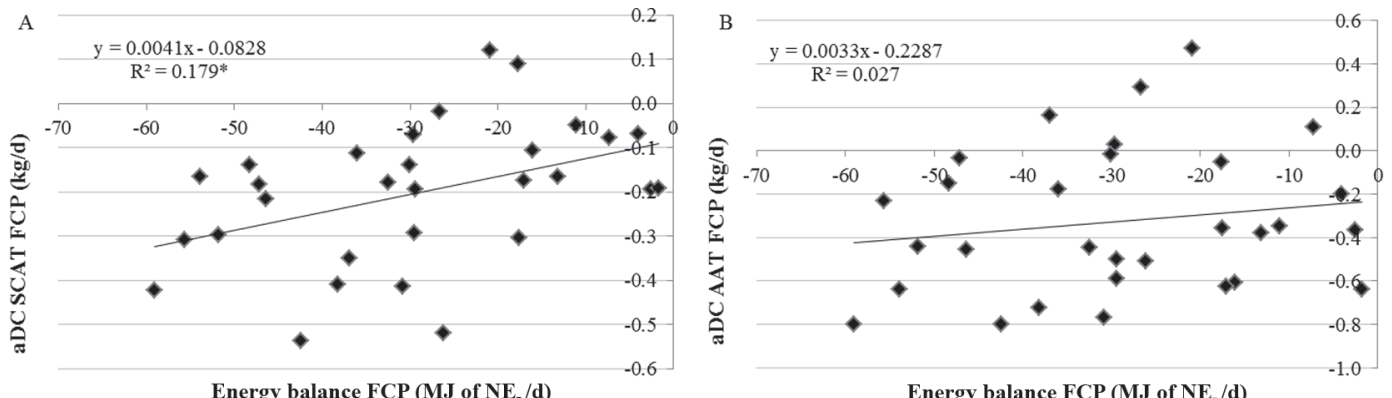

Energy balance FCP (MJ of $\left.\mathrm{NE}_{\mathrm{L}} / \mathrm{d}\right)$

Energy balance FCP (MJ of $\left.\mathrm{NE}_{\mathrm{L}} / \mathrm{d}\right)$
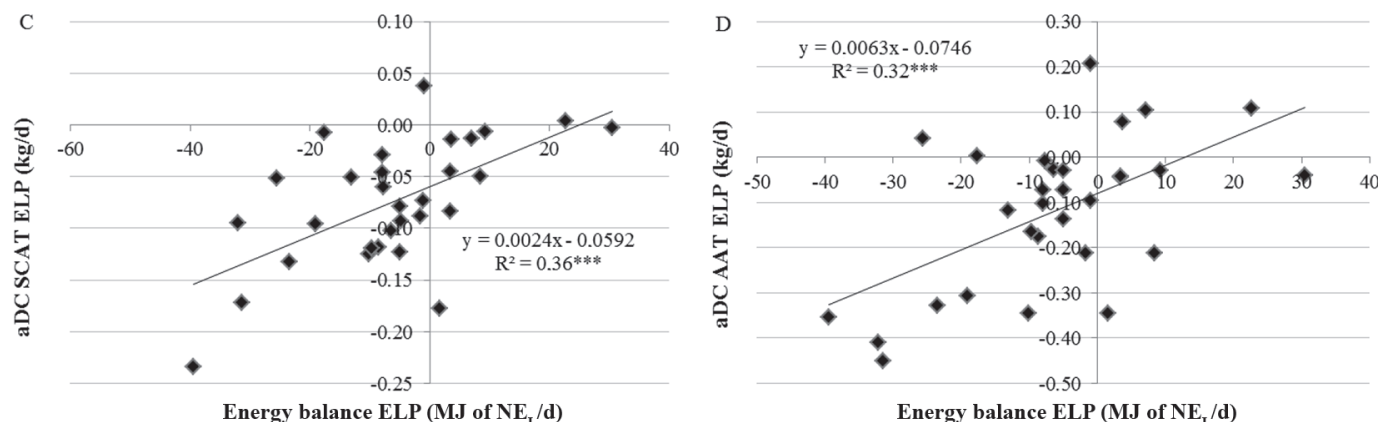

Energy balance ELP (MJ of $\mathrm{NE}_{\mathbf{L}} / \mathrm{d}$ )

Energy balance ELP (MJ of $\mathrm{NE}_{L} / d$ )

Figure 1. Relationship between mean energy balance (MJ of $\mathrm{NE}_{\mathrm{L}} / \mathrm{d}$ ) in the fresh cow period (FCP; 7 to 28 postpartum) and average daily change $(\mathrm{aDC}, \mathrm{kg} / \mathrm{d}$ ) in mass of subcutaneous adipose tissue (SCAT; A) and abdominal adipose tissue (AAT; B), and between mean energy balance in early lactation period (ELP, d 28 to 70 postpartum) and aDC of SCAT (C) and AAT (D) in ELP. ${ }^{*} P<0.05,{ }^{* * *} P<0.001$.
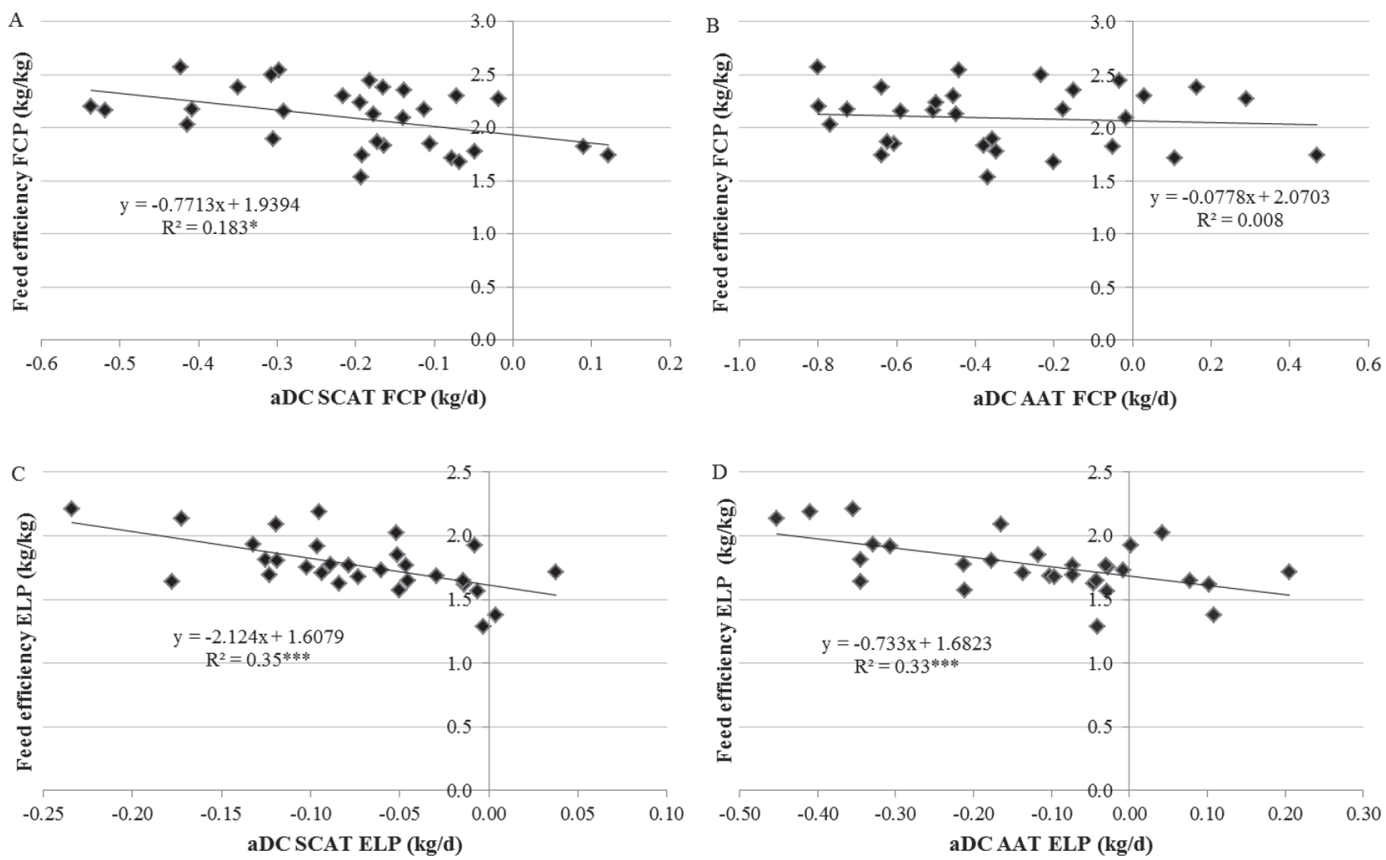

Figure 2. Relationship between average daily change (aDC, $\mathrm{kg} / \mathrm{d}$ ) in mass of subcutaneous adipose tissue (SCAT; A) and abdominal adipose tissue (AAT; B) in the fresh cow period (FCP; d 7 to 28 postpartum) and mean feed efficiency (ECM yield/DMI; $\mathrm{kg} / \mathrm{kg}$ ) in FCP and between aDC of SCAT (C) and AAT (D) in early lactation period (ELP, d 28 to 70 postpartum) and mean feed efficiency in ELP. ${ }^{*} P<0.05, * * * P<$ 0.001 
HBC and LBC groups more SCAT and AAT mass was mobilized compared with the ELP. Furthermore, cows of the HBC group mobilized significantly more depot mass not only from subcutaneous but also from abdominal depots than did cows of the LBC group. It was also not surprising (Schröder and Staufenbiel, 2006; Roche et al., 2009; van der Drift et al., 2012) that a high adipose depot mass at parturition resulted in greater loss of adipose tissue mass after parturition in SCAT and also in all assessed abdominal depots, as indicated by the negative correlation between eDM at $\mathrm{d} 7$ with aDC in the corresponding depot mass in FCP and ELP. However, as previously reported by von Soosten et al. (2011), Drackley et al. (2014), and Ruda et al. (2019), as in the current study, after parturition generally more fat was mobilized from AAT depots than from SCAT. This is possibly due not only to the bigger depot size of AAT but also to higher lipolytic activity in AAT compared with SCAT in states of NEB (Ruda et al., 2019). In the current study, the mobilized AAT mass in the HBC compared with the LBC group originated mainly from RPAT and OMAT, because MAT revealed no group differences. In contrast with this finding, Ruda et al. (2019) found the same dynamic pattern for RPAT, OMAT, and MAT after parturition in loss of adipose tissue mass. Additionally, Ruda et al. (2019) reported that not only was the absolute amount of fat mobilized from AAT greater than that of SCAT, but the relative mobilization aDC in percent of eDM (rDC1) was also greater, indicating higher lipolytic activity in AAT than in SCAT. However, the results of this study do not clearly support the observation of Ruda et al. (2019). Although after parturition rDC2 of AAT was at least numerically higher compared with SCAT, rDC1 was lower. Methodological differences may explain the differences in results. In the present study, the sonographically assessed eDM of AAT was calculated as the sum of eDM of RPAT, OMAT, and MAT, whereas Ruda et al. (2019) estimated eDM of AAT via a similar sonographic examination technique but using a different equation for sonographic measurements. Additionally, after parturition, Ruda and co-authors examined cows sonographically at $\mathrm{d} 3$ and not at $\mathrm{d} 7$, as was performed in this study for technical reasons, resulting in slightly different periods.

The significant correlations between depot mass gain during the DP and loss of depot mass in the FCP in abdominal but not subcutaneous adipose depots may indicate a functional disparity between AAT and SCAT. In other words, the more an abdominal depot gains mass during DP, the more mass is mobilized in FCP, which apparently is not the case for SCAT. The significant correlation between mean EB during the DP and depot mass gain of SCAT but not of AAT may also hint toward a depot functional disparity and that gain of AAT is unrelated or less related to EB during this period, compared with gain of SCAT. Body condition generally has a relatively low heritability (Dal Zotto et al., 2007: 0.15; Battagin et al., 2013: 0.114). However, studies on genetic disposition consider only subcutaneous but not abdominal depots. Independently from $\mathrm{EB}$, an individual disposition may exist to gain more before and to lose more AAT after parturition, and a functional interaction may exist between gain and mobilization around parturition from abdominal depots. Still, in contrast with this study, Ruda et al. (2019), in a study on 18 primiparous and 29 multiparous cows, reported, in addition to the previously described relationship between gain and loss of abdominal depots, a significant correlation between gain in SCAT during DP and loss of SCAT during FCP. As in this study, Ruda and co-authors found no correlations between gain in DP and loss of depot mass in ELP.

According to Schröder and Staufenbiel (2006), Roche et al. (2009), and Contreras et al. (2018), it is generally assumed that, in postpartum dairy cows, greater NEB commonly induces more severe lipomobilization. However, in the present study, this relationship was reflected only by results of correlation analysis between mean EB and aDC of SCAT and aDC of AAT during ELP. The more severe NEB was, the more adipose mass was mobilized from SCAT and AAT after $28 \mathrm{~d}$ in lactation. During FCP we found only a weak correlation with NEB for aDC of SCAT but not AAT. This observation may also indicate a functional disparity between SCAT and AAT in FCP. Furthermore, it calls into question the idea that $\mathrm{NEB}$ is the main driver of lipomobilization of AAT during FCP. Instead, this observation suggests that, during this particular phase, factors other than NEB may be more important. Results of the present study again point to an individual's body condition as one of these possible factors enhancing postpartum adipose mobilization in the dairy cow (Roche et al., 2009; Vanholder et al., 2015; Ruda et al., 2019). Moreover, it is conceivable that mechanisms of homeorhetic adaptation to lactation might play a greater role than NEB in the depletion of adipose depots during FCP. Decoupling of the somatotropic axis (Gross et al., 2011; Piechotta et al., 2013; Gross and Bruckmaier, 2019a) may be involved in differences in homeorhetic adaptation of these depots. Conceivably, depot tissues may differ in responsiveness to insulin or $\beta$-adrenergic stimulation of lipolysis (Sumner and McNamara, 2007; Sumner-Thomson et al., 2011; Kenéz et al., 2015; Kinoshita et al., 2016), as well as in presence or responsiveness to inflammatory stimuli (McGrattan et al., 2000; De Koster et al., 2016; Contreras et al., 2017). 
During the DP, mean blood concentrations of BHB were significantly higher in cows of the HBC group than in the LBC group. Generally, blood concentrations of $\mathrm{BHB}$ are a function of ruminal and hepatic BHB release and utilization in peripheral tissues. Because mean gain of SCAT and AAT mass, DMI, EI, and EB in the DP did not differ significantly between groups, less activity of HBC cows may be a possible explanation, causing less utilization of BHB by peripheral tissues and thus elevated blood concentrations (Drackley et al., 2001). Postpartum, the expected higher incidence of SCK during FCP was not observed in cows of the HBC compared with the LBC group (SCK incidence: $60 \%$ vs. $50 \%$, respectively; data not significant, $P>0.1$ ), but the incidence was within the range reported in earlier studies (Duffield et al., 1998; Roche et al., 2009; McArt et al., 2012; Suthar et al., 2013). A high incidence of SCK may be attributable to the high calving BCS of the cows enrolled in the study, as reported by Gillund et al. (2001). Dairy cows calving with BCS $>3.5$ have a significantly higher risk of developing ketosis compared with a calving BCS of 3.25. Thus, the high incidence of SCK may be a consequence of the animal model used during this study.

In the FCP, significant amounts of fat were mobilized from AAT. Glycerol and NEFA from lipolysis out of AAT are drained via the portal vein to the liver (Montague and O'Rahilly, 2000; Fiore et al., 2018), thereby providing an immediate energy flux to meet the energy demands of this organ, which are particularly high in high-producing dairy cows (Reynolds et al., 2003). Ketogenesis is an alternative pathway for hepatic use of NEFA when complete oxidation of NEFA in the Krebs cycle, in case of oxaloacetate shortage, is not possible (Drackley, 1999). The almost absent correlations between mobilization of AAT mass and blood BHB concentrations in the FCP indicate that, in addition to high amounts of NEFA supplied to the liver, individual factors are responsible for significantly enhanced ketogenesis and SCK. Heritability of ketosis is about 0.1 (Weigel et al., 2017; Klein et al., 2019).

The higher mean blood NEFA concentrations after parturition in the HBC compared with the LBC group reflect NEB with subsequent compensatory release of NEFA from adipose tissues (Duffield, 2000). At least the lack of significant differences in daily activity between groups gave no indication of reduced utilization of NEFA by peripheral tissues caused by less physical activity. The correlation analysis also showed that the more adipose tissue was mobilized from SCAT and AAT, the higher blood NEFA concentrations were found. We found that NEFA concentration started to increase 1 wk before parturition and tended to be higher in HBC cows. These findings were similar to those of Pires et al. (2013) and Weber et al. (2013).

The more extensive mobilization of fat from adipose tissues in the HBC group at least partly explains the higher milk fat content (Stockdale, 2005; Gross and Bruckmaier, 2019b). This is also indicated by a weak but significant correlation between mobilization of adipose mass from SCAT and OMAT with milk fat content. The higher milk fat content resulted in higher recorded mean FCM and ECM and, in consequence, in higher mean FE in HBC compared with the LBC group. Because mean DMI did not differ between HBC and LBC groups, the higher calculated FE (Schäfers et al., 2017) was mainly caused by increased ECM. That a higher FE in lactating cows in NEB is, to a significant extent, attributable to the extra energy provided by fat mobilization in ELP is also indicated by the significant correlation with aDC of SCAT and AAT in ELP. However, in the first 4 wk after parturition, only aDC of SCAT but not of AAT contributed to higher FE. This may indicate, again, a functional disparity and a different fate of NEFA from SCAT and AAT in the first weeks of lactation. Additionally, FE appears not to be a suitable criterion for evaluation of performance of dairy cows in NEB. Spurlock et al. (2012) reported an unfavorable genetic correlation between higher $\mathrm{FE}$ and a more pronounced NEB after parturition, indicating also that, according to FE, "efficient" cows may be more susceptible to excessive lipomobilization and subsequently metabolic disorders (Bach et al., 2019).

\section{CONCLUSIONS}

According to this study, German Holstein cows store about 2 to 3 times more fat in abdominal than in subcutaneous adipose tissues. During positive energy balance in the dry period, significantly more fat is stored in abdominal than in subcutaneous depots, and during negative energy balance after parturition, more adipose tissue mass is lost from abdominal compared with subcutaneous depots. Cows with high compared with low body condition before calving gain about the same mass of adipose tissue in abdominal and subcutaneous depots during the dry period but mobilize significantly more adipose tissue mass from both depots after calving. Various observations indicate a functional disparity between abdominal and subcutaneous adipose tissues. In contrast to subcutaneous adipose tissues, (I) the amount of abdominal adipose mass lost in the first 4 wk postpartum appears closely related to gain of mass during the dry period. (II) Gain prepartum and (III) loss during the first weeks postpartum of adipose mass in abdominal tissues seems unrelated or only margin- 
ally related to energy balance of respective periods, and (IV) the relation between loss of adipose mass from AAT to feed efficiency appears negligible in the first 4 wk postpartum. Feed efficiency appears not be a suitable criterion for evaluation of performance of dairy cows in negative energy balance.

\section{ACKNOWLEDGMENTS}

The authors thank co-workers at the Institute of Animal Nutrition and the Experimental Station of the Friedrich-Loeffler-Institute in Brunswick, Germany, for performing the experiment and analyses. Many thanks are also due to Claudia Raschka (Clinic for Cattle, University of Veterinary Medicine Hannover, Foundation, Hannover, Germany) for familiarization with the method of ultrasonographic assessment of different fat depots and to Caroline Drong (Institute of Animal Nutrition, Friedrich-Loeffler-Institute, Federal Research Institute for Animal Health, Braunschweig, Germany) for her help in analyzing the samples. The study was supported by Badische Anilin- \& Soda-Fabrik (BASF), Ludwigshafen, Germany. The authors have not stated any conflicts of interest.

\section{REFERENCES}

Bach, A., M. Terre, and M. Vidal. 2019. Symposium review: Decomposing efficiency of milk production and maximizing profit. J. Dairy Sci. 103:5709-5725. https://doi.org/10.3168/jds.2019-17304.

Battagin, M., C. Sartori, S. Biffani, M. Penasa, and M. Cassandro. 2013. Genetic parameters for body condition score, locomotion, angularity, and production traits in Italian Holstein cattle. J. Dairy Sci. 96:5344-5351. https://doi.org/10.3168/jds.2012-6352.

Bewley, J. M., R. E. Boyce, J. Hockin, L. Munksgaard, S. D. Eicher, M. E. Einstein, and M. M. Schutz. 2010. Influence of milk yield, stage of lactation, and body condition on dairy cattle lying behaviour measured using an automated activity monitoring sensor. J. Dairy Res. 77:1-6. https://doi.org/10.1017/S0022029909990227.

Contreras, G. A., C. Strieder-Barboza, and J. De Koster. 2018. Symposium review: Modulating adipose tissue lipolysis and remodeling to improve immune function during the transition period and early lactation of dairy cows. J. Dairy Sci. 101:2737-2752. https://doi .org/10.3168/jds.2017-13340.

Contreras, G. A., C. Strieder-Barboza, and W. Raphael. 2017. Adipose tissue lipolysis and remodeling during the transition period of dairy cows. J. Anim. Sci. Biotechnol. 8:41. https://doi.org/10 1186/s40104-017-0174-4.

Dal Zotto, R., M. De Marchi, C. Dalvit, M. Cassandro, L. Gallo, P. Carnier, and G. Bittante. 2007. Heritabilities and genetic correlations of body condition score and calving interval with yield, somatic cell score, and linear type traits in Brown Swiss cattle. J. Dairy Sci. 90:5737-5743. https://doi.org/10.3168/jds.2007-0280.

De Koster, J., W. Van den Broeck, L. Hulpio, E. Claeys, M. Van Eetvelde, K. Hermans, M. Hostens, V. Fievez, and G. Opsomer. 2016. Influence of adipocyte size and adipose depot on the in vitro lipolytic activity and insulin sensitivity of adipose tissue in dairy cows at the end of the dry period. J. Dairy Sci. 99:2319-2328. https:// doi.org/10.3168/jds.2015-10440.

Drackley, J. K. 1999. ADSA Foundation Scholar Award. Biology of dairy cows during the transition period: The final frontier? J. Dairy Sci. 82:2259-2273. https://doi.org/10.3168/jds.S0022 -0302(99)75474-3.
Drackley, J. K., T. R. Overton, and G. N. Douglas. 2001. Adaptations of glucose and long-chain fatty acid metabolism in liver of dairy cows during the periparturient period. J. Dairy Sci. 84:E100-E112. https://doi.org/10.3168/jds.S0022-0302(01)70204-4.

Drackley, J. K., R. L. Wallace, D. Graugnard, J. Vasquez, B. F. Richards, and J. J. Loor. 2014. Visceral adipose tissue mass in nonlactating dairy cows fed diets differing in energy density. J. Dairy Sci. 97:3420-3430. https://doi.org/10.3168/jds.2014-8014.

Duffield, T. 2000. Subclinical ketosis in lactating dairy cattle. Vet. Clin. North Am. Food Anim. Pract. 16:231-253. https://doi.org/ 10.1016/S0749-0720(15)30103-1.

Duffield, T. F., D. Sandals, K. E. Leslie, K. Lissemore, B. W. McBride, J. H. Lumsden, P. Dick, and R. Bagg. 1998. Effect of prepartum administration of monensin in a controlled-release capsule on postpartum energy indicators in lactating dairy cows. J. Dairy Sci. 81:2354-2361. https://doi.org/10.3168/jds.S0022-0302(98)70126 -2 .

Edmonson, A. J., I. J. Lean, L. D. Weaver, T. Farver, and G. Webster. 1989. A body condition scoring chart for Holstein dairy cows. J. Dairy Sci. 72:68-78. https://doi.org/10.3168/jds.S0022 $-0302(89) 79081-0$

Fiore, E., L. Perillo, M. Morgante, E. Giudice, B. Contiero, G. Curone, E. Manuali, S. Pavone, G. Piccione, and M. Gianesella. 2018. Ultrasonographic measurement of liver, portal vein, hepatic vein and perivisceral adipose tissue in high-yielding dairy cows with fatty liver during the transition period. J. Dairy Res. 85:431-438. https: //doi.org/10.1017/S0022029918000754.

Fregonesi, J. A., and J. D. Leaver. 2001. Behaviour, performance and health indicators of welfare for dairy cows housed in strawyard or cubicle systems. Livest. Prod. Sci. 68:205-216. https://doi.org/10 .1016/S0301-6226(00)00234-7.

Gillund, P., O. Reksen, Y. T. Grohn, and K. Karlberg. 2001. Body condition related to ketosis and reproductive performance in Norwegian dairy cows. J. Dairy Sci. 84:1390-1396. https://doi.org/10 .3168/jds.S0022-0302(01)70170-1.

Gross, J., H. A. van Dorland, F. J. Schwarz, and R. M. Bruckmaier. 2011. Endocrine changes and liver mRNA abundance of somatotropic axis and insulin system constituents during negative energy balance at different stages of lactation in dairy cows. J. Dairy Sci. 94:3484-3494. https://doi.org/10.3168/jds.2011-4251.

Gross, J. J., and R. M. Bruckmaier. 2019a. Invited review: Metabolic challenges and adaptation during different functional stages of the mammary gland in dairy cows: Perspectives for sustainable milk production. J. Dairy Sci. 102:2828-2843. https://doi.org/10.3168/ jds.2018-15713.

Gross, J. J., and R. M. Bruckmaier. 2019b. Review: Metabolic challenges in lactating dairy cows and their assessment via established and novel indicators in milk. Animal 13(Suppl. 1):s75-s81.

Grummer, R. R. 1995. Impact of changes in organic nutrient metabolism on feeding the transition dairy cow. J. Anim. Sci. 73:28202833. https://doi.org/10.2527/1995.7392820x.

Haley, D. B., A. M. de Passille, and J. Rushen. 2001. Assessing cow comfort: Effects of two floor types and two tie stall designs on the behaviour of lactating dairy cows. Appl. Anim. Behav. Sci 71:105-117. https://doi.org/10.1016/S0168-1591(00)00175-1.

Kabara, E., L. M. Sordillo, S. Holcombe, and G. A. Contreras. 2014. Adiponectin links adipose tissue function and monocyte inflammatory responses during bovine metabolic stress. Comp. Immunol. Microbiol. Infect. Dis. 37:49-58. https://doi.org/10.1016/j.cimid .2013.10.007.

Kenéz, A., R. Tienken, L. Locher, U. Meyer, A. Rizk, J. Rehage, S. Dänicke, and K. Huber. 2015. Changes in lipid metabolism and $\beta$-adrenergic response of adipose tissues of periparturient dairy cows affected by an energy-dense diet and nicotinic acid supplementation. J. Anim. Sci. 93:4012-4022. https://doi.org/10.2527/ jas.2014-8833.

Kim, N., V. Amin, D. Wilson, G. Rouse, and S. Udpa. 1998. Ultrasound image texture analysis for characterizing intramuscular fat content of live beef cattle. Ultrason. Imaging 20:191-205. https:// doi.org/10.1177/016173469802000304. 
Kinoshita, A., Á. Kenéz, L. Locher, U. Meyer, S. Dänicke, J. Rehage, and K. Huber. 2016. Insulin signaling in liver and adipose tissues in periparturient dairy cows supplemented with dietary nicotinic acid. PLoS One 11:e0147028. https://doi.org/10.1371/journal pone.0147028

Klein, S. L., C. Scheper, K. Brugemann, H. H. Swalve, and S. Konig. 2019. Phenotypic relationships, genetic parameters, genome-wide associations, and identification of potential candidate genes for ketosis and fat-to-protein ratio in German Holstein cows. J. Dairy Sci. 102:6276-6287. https://doi.org/10.3168/jds.2019-16237.

Leblanc, S. 2010. Monitoring metabolic health of dairy cattle in the transition period. J. Reprod. Dev. 56(Suppl.):S29-S35. https://doi .org/10.1262/jrd.1056S29.

Littell, R. C., P. R. Henry, and C. B. Ammerman. 1998. Statistical analysis of repeated measures data using SAS procedures. J. Anim. Sci. 76:1216-1231. https://doi.org/10.2527/1998.7641216x.

Locher, L. F., N. Meyer, E. M. Weber, J. Rehage, U. Meyer, S. Danicke, and K. Huber. 2011. Hormone-sensitive lipase protein expression and extent of phosphorylation in subcutaneous and retroperitoneal adipose tissues in the periparturient dairy cow. J. Dairy Sci. 94:4514-4523. https://doi.org/10.3168/jds.2011-4145.

McArt, J. A. A., D. V. Nydam, and G. R. Oetzel. 2012. Epidemiology of subclinical ketosis in early lactation dairy cattle. J. Dairy Sci. 95:5056-5066. https://doi.org/10.3168/jds.2012-5443.

McGrattan, P. D., A. R. G. Wylie, and J. Nelson. 2000. Tissue-specific differences in insulin binding affinity and insulin receptor concentrations in skeletal muscles, adipose tissue depots and liver of cattle and sheep. Anim. Sci. 71:501-508. https://doi.org/10.1017/ S1357729800055466.

Montague, C. T., and S. O'Rahilly. 2000. The perils of portliness: Causes and consequences of visceral adiposity. Diabetes 49:883888. https://doi.org/10.2337/diabetes.49.6.883.

Nielsen, P. P., I. Fontana, K. H. Sloth, M. Guarino, and H. Blokhuis. 2018. Technical note: Validation and comparison of 2 commercially available activity loggers. J. Dairy Sci. 101:5449-5453. https://doi .org/10.3168/jds.2017-13784.

Ospina, P. A., D. V. Nydam, T. Stokol, and T. R. Overton. 2010. Evaluation of nonesterified fatty acids and $\beta$-hydroxybutyrate in transition dairy cattle in the northeastern United States: Critical thresholds for prediction of clinical diseases. J. Dairy Sci. 93:546554. https://doi.org/10.3168/jds.2009-2277.

Peres, A. M., L. G. Dias, M. Joy, and A. Teixeira. 2010. Assessment of goat fat depots using ultrasound technology and multiple multivariate prediction models. J. Anim. Sci. 88:572-580. https://doi .org/10.2527/jas.2009-2195.

Piechotta, M., K. Kedves, M. G. Araujo, A. Hoeflich, F. Metzger, M. Heppelmann, A. Muscher-Banse, C. Wrenzycki, C. Pfarrer, H. J. Schuberth, M. Hoedemaker, H. Bollwein, and M. Kaske. 2013. Hepatic mRNA expression of acid labile subunit and deiodinase 1 differs between cows selected for high versus low concentrations of insulin-like growth factor 1 in late pregnancy. J. Dairy Sci. 96:3737-3749. https://doi.org/10.3168/jds.2012-6341.

Pires, J. A., C. Delavaud, Y. Faulconnier, D. Pomies, and Y. Chilliard. 2013. Effects of body condition score at calving on indicators of fat and protein mobilization of periparturient Holstein-Friesian cows. J. Dairy Sci. 96:6423-6439. https://doi.org/10.3168/jds.2013 $-6801$.

Raschka, C., L. Ruda, P. Wenning, C.-I. von Stemm, C. Pfarrer, K. Huber, U. Meyer, S. Dänicke, and J. Rehage. 2016. In vivo determination of subcutaneous and abdominal adipose tissue depots in German Holstein dairy cattle. J. Anim. Sci. 94:2821-2834. https:/ /doi.org/10.2527/jas.2015-0103.

Reynolds, C. K., P. C. Aikman, B. Lupoli, D. J. Humphries, and D. E. Beever. 2003. Splanchnic metabolism of dairy cows during the transition from late gestation through early lactation. J. Dairy Sci. 86:1201-1217. https://doi.org/10.3168/jds.S0022-0302(03)73704 $-7$.

Ribeiro, F. R., and L. O. Tedeschi. 2012. Using real-time ultrasound and carcass measurements to estimate total internal fat in beef cattle over different breed types and managements. J. Anim. Sci. 90:3259-3265. https://doi.org/10.2527/jas.2011-4697.

Ripoll, G., M. Joy, and A. Sanz. 2010. Estimation of carcass composition by ultrasound measurements in 4 anatomical locations of 3 commercial categories of lamb. J. Anim. Sci. 88:3409-3418. https: //doi.org/10.2527/jas.2009-2632.

Roche, J. R., N. C. Friggens, J. K. Kay, M. W. Fisher, K. J. Stafford, and D. P. Berry. 2009. Invited review: Body condition score and its association with dairy cow productivity, health, and welfare. J. Dairy Sci. 92:5769-5801. https://doi.org/10.3168/jds.2009-2431.

Roche, J. R., J. K. Kay, N. C. Friggens, J. J. Loor, and D. P. Berry. 2013. Assessing and managing body condition score for the prevention of metabolic disease in dairy cows. Vet. Clin. North Am. Food Anim. Pract. 29:323-336. https://doi.org/10.1016/j.cvfa.2013.03 .003 .

Ruda, L., C. Raschka, K. Huber, R. Tienken, U. Meyer, S. Danicke, and J. Rehage. 2019. Gain and loss of subcutaneous and abdominal fat depot mass from late pregnancy to 100 days in milk in German Holsteins. J. Dairy Res. 86:296-302. https://doi.org/10 $.1017 /$ S0022029919000542.

Saremi, B., S. Winand, P. Friedrichs, A. Kinoshita, J. Rehage, S. Danicke, S. Haussler, G. Breves, M. Mielenz, and H. Sauerwein. 2014. Longitudinal profiling of the tissue-specific expression of genes related with insulin sensitivity in dairy cows during lactation focusing on different fat depots. PLoS One 9:e86211. https:// doi.org/10.1371/journal.pone.0086211.

Schäfers, S., D. von Soosten, U. Meyer, C. Drong, J. Frahm, J. Kluess, C. Raschka, J. Rehage, A. Troscher, W. Pelletier, and S. Danicke. 2017. Influence of conjugated linoleic acid and vitamin $\mathrm{E}$ on performance, energy metabolism, and change of fat depot mass in transitional dairy cows. J. Dairy Sci. 100:3193-3208. https://doi .org/10.3168/jds.2016-11882.

Schröder, U. J., and R. Staufenbiel. 2006. Invited review: Methods to determine body fat reserves in the dairy cow with special regard to ultrasonographic measurement of backfat thickness. J. Dairy Sci. 89:1-14. https://doi.org/10.3168/jds.S0022-0302(06)72064-1.

Shepley, E., G. Obinu, T. Bruneau, and E. Vasseur. 2019. Housing tiestall dairy cows in deep-bedded pens during an 8-week dry period: Effects on lying time, lying postures, and rising and lying-down behaviors. J. Dairy Sci. 102:6508-6517. https://doi.org/10.3168/ jds.2018-15859.

Spurlock, D. M., J. C. Dekkers, R. Fernando, D. A. Koltes, and A. Wolc. 2012. Genetic parameters for energy balance, feed efficiency, and related traits in Holstein cattle. J. Dairy Sci. 95:5393-5402. https://doi.org/10.3168/jds.2012-5407.

Stockdale, C. R. 2005. Investigating the interaction between body condition at calving and pre-calving energy and protein nutrition on the early lactation performance of dairy cows. Aust. J. Exp. Agric. 45:1507-1518. https://doi.org/10.1071/EA04104.

Sumner, J. M., and J. P. McNamara. 2007. Expression of lipolytic genes in the adipose tissue of pregnant and lactating Holstein dairy cattle. J. Dairy Sci. 90:5237-5246. https://doi.org/10.3168/ jds.2007-0307.

Sumner-Thomson, J. M., J. L. Vierck, and J. P. McNamara. 2011. Differential expression of genes in adipose tissue of first-lactation dairy cattle. J. Dairy Sci. 94:361-369. https://doi.org/10.3168/jds .2010-3447.

Suthar, V. S., J. Canelas-Raposo, A. Deniz, and W. Heuwieser. 2013. Prevalence of subclinical ketosis and relationships with postpartum diseases in European dairy cows. J. Dairy Sci. 96:2925-2938. https://doi.org/10.3168/jds.2012-6035.

Teixeira, A., M. Joy, and R. Delfa. 2008. In vivo estimation of goat carcass composition and body fat partition by real-time ultrasonography. J. Anim. Sci. 86:2369-2376. https://doi.org/10.2527/jas 2007-0367.

Trénel, P., M. B. Jensen, E. L. Decker, and F. Skjøth. 2009. Technical note: Quantifying and characterizing behavior in dairy calves using the IceTag automatic recording device. J. Dairy Sci. 92:3397-3401. https://doi.org/10.3168/jds.2009-2040. 
van der Drift, S. G., M. Houweling, J. T. Schonewille, A. G. Tielens, and R. Jorritsma. 2012. Protein and fat mobilization and associations with serum $\beta$-hydroxybutyrate concentrations in dairy cows. J. Dairy Sci. 95:4911-4920. https://doi.org/10.3168/jds.2011-4771.

van Knegsel, A. T. M., S. G. A. van der Drift, J. Čermáková, and B. Kemp. 2013. Effects of shortening the dry period of dairy cows on milk production, energy balance, health, and fertility: A systematic review. Vet. J. 198:707-713. https://doi.org/10.1016/j.tvjl 2013.10.005.

Vanholder, T., J. Papen, R. Bemers, G. Vertenten, and A. C. Berge. 2015. Risk factors for subclinical and clinical ketosis and association with production parameters in dairy cows in the Netherlands. J. Dairy Sci. 98:880-888. https://doi.org/10.3168/jds.2014-8362.

Vasseur, E., J. Rushen, D. B. Haley, and A. M. de Passille. 2012. Sampling cows to assess lying time for on-farm animal welfare assessment. J. Dairy Sci. 95:4968-4977. https://doi.org/10.3168/ jds.2011-5176.

VDLUFA. 1993. Handbuch der Landwirtschaftlichen Versuchs- und Untersuchungsmethodik (VDLUFA- Methodenbuch). Vol. III. VDLUFA-Verlag, Darmstadt, Germany.

von Soosten, D., U. Meyer, E. M. Weber, J. Rehage, G. Flachowsky, and S. Danicke. 2011. Effect of trans-10,cis-12 conjugated linoleic acid on performance, adipose depot weights, and liver weight in early-lactation dairy cows. J. Dairy Sci. 94:2859-2870. https://doi .org/10.3168/jds.2010-3851.
Weber, C., C. Hametner, A. Tuchscherer, B. Losand, E. Kanitz, W. Otten, S. P. Singh, R. M. Bruckmaier, F. Becker, W. Kanitz, and H. M. Hammon. 2013. Variation in fat mobilization during early lactation differently affects feed intake, body condition, and lipid and glucose metabolism in high-yielding dairy cows. J. Dairy Sci. 96:165-180. https://doi.org/10.3168/jds.2012-5574.

Weigel, K. A., R. S. Pralle, H. Adams, K. Cho, C. Do, and H. M. White. 2017. Prediction of whole-genome risk for selection and management of hyperketonemia in Holstein dairy cattle. J. Anim. Breed. Genet. 134:275-285. https://doi.org/10.1111/jbg.12259.

Westin, R., A. Vaughan, A. M. de Passillé, T. J. DeVries, E. A. Pajor, D. Pellerin, J. M. Siegford, E. Vasseur, and J. Rushen. 2016. Lying times of lactating cows on dairy farms with automatic milking systems and the relation to lameness, leg lesions, and body condition score. J. Dairy Sci. 99:551-561. https://doi.org/10.3168/jds .2015-9737.

Wright, I. A., and A. J. F. Russel. 1984. Partition of fat, body composition and body condition score in mature cows. Anim. Sci. 38:2332. https://doi.org/10.1017/S0003356100041313.

Yang, X., and U. Smith. 2007. Adipose tissue distribution and risk of metabolic disease: Does thiazolidinedione-induced adipose tissue redistribution provide a clue to the answer? Diabetologia 50:11271139. https://doi.org/10.1007/s00125-007-0640-1. 